\title{
COMMUNITY HEALTH CENTRES AS THE PHARMACEUTICAL SERVICES SUPPORT SYSTEM IN HEALTHY INDONESIA PROGRAM: AN OBSERVATIONAL STUDY IN WEST JAVA INDONESIA
}

\author{
ZAENAL KOMAR ${ }^{1}$, KERI LESTARI' ${ }^{1}$, ANNA MEILIANA ${ }^{1}$, ALI GUFRON MUKTI², YANA IRAWATI ${ }^{3}$, \\ MIFTAHUDINIYAH ${ }^{3}$, NURRANI MUSTIKA DEWI ${ }^{4}$
}

1Department of Pharmacology and Clinical Pharmacy, Faculty of Pharmacy, Universitas Padjadjaran, Jl Raya Bandung Sumedang km 21, Jatinangor, West Java 45363, Indonesia, ${ }^{2}$ Ministry of Research, Technology and Higher Education of the Republic of Indonesia, Gedung D Pintu Satu Senayan, Central Jakarta, 10270, Indonesia, ${ }^{3}$ Jakarta National Health Training Centre, Jl Wijaya Kusuma 45, Jakarta 12430, Indonesia, ${ }^{4}$ Prodia Clinical Laboratory, Jl Kramat Raya 150, Jakarta Pusat 10430, Indonesia

*Email: nurranimustika@gmail.com

Received: 20 Aug 2021, Revised and Accepted: 02 Oct 2021

\section{ABSTRACT}

Objective: The Healthy Indonesia Programme with a family approach strategy was launched by the Indonesian government in 2015 . Pharmaceutical service, including drug supply management and clinical pharmacy, is one of the essential components for the program implementation. This study was aimed to evaluate the pharmaceutical services support in the Healthy Indonesia Programme in West Java Indonesia.

Methods: This was a cross-sectional study observed on pharmaceutical services under the family approach programme description. A selfcompleted questionnaire was distributed to 39 accredited community health centres (CHCs) in West Java, Indonesia. Several indicators of the Standard Pharmacy Services were assessed.

Results: Thirty-nine CHCs were involved in this study. Most of the CHCs were accredited as intermediate (59\%) and have applied good pharmaceuticals and consumables inventory management. The online system and more training will give room for improvement. A big gap was found in human resources number and competencies, impact on clinical pharmacy standard services including counselling services (23.1\%) and home visit (7.7\%).

Conclusion: Applying an online system is needed to improve the inventory management system in CHCs. The quality of clinical pharmacy standard services in CHCs can be improved by fulfilling the minimum numbers and competencies of human resources.

Keywords: Clinical pharmacy, Family approach, Pharmaceutical management system

(C) 2021 The Authors. Published by Innovare Academic Sciences Pvt Ltd. Thisis an open access article under the CC BYlicense (https://creativecommons.org/licenses/by/4.0/) DOI: https://dx.doi.org/10.22159/ijap.2021.v13s4.43862 Journal homepage: https://innovareacademics.in/journals/index.php/ijap

\section{INTRODUCTION}

Community Health Centres (CHC) are the first line of curative, promotive, and preventive healthcare services facility for population on subdistrict level. In Indonesia, the number of CHC keeps increasing, and up to date, there are 10,134 units of CHCs around the country [1, 2]. In 2015, as the translation of the Indonesian government's program for Healthy Indonesia Program, a family approach strategy called 'Program Indonesia Sehat-Pendekatan Keluarga' (PIS-PK) was launched to enhance the quality of Indonesian public health. This program is implemented via the $\mathrm{CHCs}$, and each $\mathrm{CHC}$ was assigned to make home visits in their working area $[3,4]$.

To assess the effectiveness of this program implementation, twelve main indicators were determined as the family health status, and one of the essential components is the pharmaceutical service [5]. Pharmaceutical service in CHCs involves two main activities, namely drug supply management and clinical pharmacy. But besides these two activities, it is also necessary to pay attention to the pharmaceutical human resources and their competencies $[2,6,7]$. Pharmaceutical services are expected to ensure the effectiveness, safety and efficiency of drugs and make sure that they are easily accessible for the public.

Even though the program has been conducted for more than five years, however, there are no comprehensive assessments for the pharmaceutical services in the CHCs during the PIS-PK implementation $[2,6]$. This study was aimed to evaluate the pharmaceutical services support during PIS-PK implementation in the West Java Province, Indonesia.

\section{MATERIALS AND METHODS}

\section{Study design}

This was a cross-sectional study observed on pharmaceutical services under the PIS-PK program description. The study was conducted using a self-completed questionnaire (Supplement 1) which evaluated several indicators including the availability of pharmacists or pharmacy technicians, drug supply management, clinical pharmacy services and the availability of drugs, represent the Standard Pharmacy Services at Health Centres published by the Ministry of Health [2], which should be applied by CHCs. The questionnaire was validated through a workshop conducted in the Ministry of Health Training Centre, Jakarta, before the study started.

\section{Respondent's recruitments}

From a total of 1,054 CHCs in West Java, we only included accredited CHCs that have previously completed the PIS-PK training program conducted by the Training Units of the Indonesian Ministry of Health. Forty CHCs from Majalengka, Indramayu, Tasikmalaya, Cianjur, Sukabumi districts and Sukabumi city, West Java, Indonesia, were participated in this study.

\section{Data collection}

The data collection in this study was conducted in the Health Training Centre, Bandung. The questionnaires were answered by the representative respondents who were responsible for drug supply management services and/or clinical pharmacy service of each CHC, including the pharmacist, pharmacy technician, human resources personnel, or other staffs CHC staff. One respondent represented by either the pharmacist or pharmacy technician was sent by each CHC to fill in the questionnaire and joined the Focus Group Discussion.

\section{Statistical analysis}

Data were analysed by the Statistical Package for Social Scientists (SPSS) v.22 (IBM Corporation, Armonk, NY, USA). Frequency analysis was performed, and the data were presented in $\mathrm{n}(\%)$.

\section{RESULTS}

From all 40 CHCs, one was excluded due to the accreditation criteria. The general characteristics of $\mathrm{CHC}$ respondents is shown in table 1 . 
Most of the CHCs in West Java were accredited as Intermediate (59\%), while the others were accredited as Basic $(33.3 \%)$ and Primary (7.7\%). Inpatient CHCs were mostly located in rural areas
(38.5\%), while outpatient CHCs were most located in urban areas (33.3\%). Neither inpatient nor outpatient CHCs was located in the remote and very remote area.

Table 1: The general characterization of CHCs and its representative

\begin{tabular}{|c|c|c|}
\hline Respondent's characteristic & $\mathbf{N}$ & $\%$ \\
\hline \multicolumn{3}{|l|}{ Gender } \\
\hline Male & 10 & 26 \\
\hline Female & 29 & 74 \\
\hline \multicolumn{3}{|l|}{ Educational background } \\
\hline Pharmacy Highschool & 4 & 10 \\
\hline Highschool & 1 & 2 \\
\hline Pharmacy Diploma & 14 & 36 \\
\hline Bachelor in Pharmacy & 19 & 49 \\
\hline Magister in Pharmacy & 2 & 3 \\
\hline \multicolumn{3}{|l|}{ CHC Area } \\
\hline Cianjur District & 4 & 10.26 \\
\hline Tasikmalaya District & 3 & 7.69 \\
\hline Majalengka District & 11 & 28.21 \\
\hline Sukabumi City & 7 & 17.95 \\
\hline Indramayu District & 6 & 15.38 \\
\hline Sukabumi District & 8 & 20.51 \\
\hline \multicolumn{3}{|l|}{ CHC Accreditation } \\
\hline Plenary & 0 & 0 \\
\hline Primary & 4 & 7.7 \\
\hline Intermediate & 23 & 59 \\
\hline Basic & 12 & 33.3 \\
\hline Unaccredited & 0 & 0 \\
\hline \multicolumn{3}{|l|}{ CHC Treatment Type } \\
\hline Inpatient $\mathrm{CHC}$ for urban area & 3 & 7.7 \\
\hline Inpatient $\mathrm{CHC}$ for rural area & 15 & 38.5 \\
\hline Inpatient $\mathrm{CHC}$ for remote and very remote area & 0 & 0 \\
\hline Outpatient $\mathrm{CHC}$ for urban area & 13 & 33.3 \\
\hline Outpatient $\mathrm{CHC}$ for rural area & 8 & 20.5 \\
\hline Outpatient $\mathrm{CHC}$ for remote and very remote area & 0 & 0 \\
\hline Total & 39 & 100 \\
\hline
\end{tabular}

Besides the two main activities, drug supply management and clinical pharmacy services, we also assessed the CHCs' human resources and competencies. The quality of CHCs' services is shown in table 2 .

Table 2: Questionnaire assessment to the CHC's quality in supporting PIS-PK program

\begin{tabular}{|c|c|c|c|c|}
\hline \multirow[t]{2}{*}{ Indicators } & \multicolumn{2}{|l|}{ Yes } & \multicolumn{2}{|l|}{ No } \\
\hline & $\mathbf{N}$ & $\%$ & $\mathbf{N}$ & $\%$ \\
\hline \multicolumn{5}{|l|}{ Human Resources and Competencies } \\
\hline $\begin{array}{l}\text { - There are a minimum of } 2 \text { pharmacy technicians for inpatients } \mathrm{CHC} \text { for an urban area, and } \\
\text { a minimum } 1 \text { pharmacy technicians for other CHCs. }\end{array}$ & 13 & 33.3 & 26 & 66.6 \\
\hline - The pharmacist and pharmacy technicians get any competency improvement training. & 8 & 20.5 & 31 & 79.5 \\
\hline - The pharmacist and pharmacy technicians performed PIS-PK in the CHC. & 30 & 76.9 & 9 & 23.1 \\
\hline \multicolumn{5}{|l|}{ Drugs supply management } \\
\hline - CHC uses Healthy Family Index Data from PIS-PK in their logistic data plan. & 11 & 28.5 & 28 & 71.5 \\
\hline $\begin{array}{l}\text { - Stock planning was determined by the previous data record for the number and type of } \\
\text { diseases, or both. }\end{array}$ & 37 & 94.9 & 2 & 5.1 \\
\hline $\begin{array}{l}\text { - The drug selection based on National Formulary and National Essential Medicine List } \\
\text { published by the Ministry of Health. }\end{array}$ & 35 & 89.7 & 4 & 10.3 \\
\hline - The stakeholders were involved in logistic data planning. & 39 & 100 & 0 & 0 \\
\hline - The CHC performs document checking on drugs received. & 39 & 100 & 0 & 0 \\
\hline - The CHCs perform organoleptic quality checks on received drugs. & 29 & 74.6 & 10 & 25.4 \\
\hline $\begin{array}{l}\text { - The } \mathrm{CHC} \text { has procedures for filing the objection if there are any differences in the quantity } \\
\text { and quality of drugs received. }\end{array}$ & 37 & 94.9 & 2 & 5.1 \\
\hline - The need for drugs is not fully met by the Public Health Office. & 39 & 100 & 0 & 0 \\
\hline - The $\mathrm{CHC}$ received the drugs regularly. & 37 & 94.9 & 2 & 5.1 \\
\hline - The $\mathrm{CHC}$ received the drugs from the Public Health Office. & 33 & 84.6 & 6 & 15.4 \\
\hline - $\mathrm{CHC}$ understands the standard pharmaceutical storage requirements. & 37 & 94.9 & 2 & 5.1 \\
\hline - The CHC has qualified pharmaceutical storage. & 14 & 35.7 & 25 & 64.3 \\
\hline - $\mathrm{CHC}$ distributes the drugs to their sub-units & 39 & 100 & 0 & 0 \\
\hline - $\mathrm{CHC}$ distributes the drugs to the external sub-units based on floor-stock & 34 & 87.7 & 5 & 12.3 \\
\hline - $\mathrm{CHC}$ uses the DURRS form to report to the District Pharmacy Installation. & 39 & 100 & 0 & 0 \\
\hline - The sub-unit uses DURRS to report to CHC. & 39 & 100 & 0 & 0 \\
\hline - Pharmaceutical supply was reported regularly. & 38 & 97.4 & 1 & 2.6 \\
\hline
\end{tabular}




\begin{tabular}{|c|c|c|c|c|}
\hline \multirow[t]{2}{*}{ Indicators } & \multicolumn{2}{|l|}{ Yes } & \multicolumn{2}{|l|}{ No } \\
\hline & $\mathbf{N}$ & $\%$ & $\mathbf{N}$ & $\%$ \\
\hline - The CHC has a team who is responsible for drug removal. & 7 & 17.9 & 32 & 82.1 \\
\hline - $\mathrm{CHC}$ understands the regulation for drug removal. & 30 & 76.9 & 9 & 23.1 \\
\hline - $\mathrm{CHC}$ understands the regulation of lost or damaged drugs. & 36 & 92.6 & 3 & 7.4 \\
\hline - $\mathrm{CHC}$ performs the drugs inventory management. & 37 & 94.9 & 2 & 5.1 \\
\hline \multicolumn{5}{|l|}{ Clinical pharmacy services } \\
\hline - Prescription was assessed before the drugs were dispensed. & 28 & 71.8 & 11 & 28.2 \\
\hline - The prescription was made by physicians or dentists. & 12 & 30.8 & 27 & 69.2 \\
\hline - Counselling services & 9 & 23.1 & 30 & 76.9 \\
\hline - Home visit & 3 & 7.7 & 36 & 92.3 \\
\hline
\end{tabular}

Abbreviations: DURRS: Drug Usage Report and Request Sheet.

In this study, $5.12 \%$ of the CHCs do not have any pharmacist and pharmacy technicians. To enhance pharmacy service quality, competent human resources were needed. Training becomes one of the strategies to empower the pharmacist competencies. However, only $20.5 \%$ of pharmacists in this study have attended the training.

A number of PIS-PK indicators involve pharmacists and pharmacy technicians, including family planning, vaccination for babies, toddler's growth monitoring, tuberculosis patient treatments, hypertensive patient's treatments, and patients with mental disorders treatments. From the data, it was found that as much as $76.5 \%$ of pharmacists and pharmacy technicians have been involved in the implementation of the PIS-PK program.

As much as $94.9 \%$ CHCs in West Java Province has applied the Healthy Family Index Data system for drug stock planning, completed with previous data of drug consumption and pattern of diseases. The National Formulary and National Essential Medicine List published by the Ministry of Health was also used to determine the standard drugs for $89.7 \%$ CHC. The data showed that even though the Public Health Office regularly sends the drugs needed for the CHCs, the drug needs cannot be wholly fulfilled. Thus, CHCs utilised the capitation funds to fill the gap. Data from this study showed that almost all CHCs understand the principle of drug storage, and the concept of First Expire First Out (FEFO) and First In First Out (FIFO). However, only 35.7\% CHCs have a qualified storage system (light, air circulation, humidity, volume, etc).

The CHCs have actively distributed pharmaceuticals and consumables to their sub-units according to the prescriptions and floor stock principles. Drug Usage Report and Request Sheet (DURRS) was used as a standard reporting system in CHCs. It records the initial stock, received drugs, distributed drugs, optimal drugs stock number, and the requested drugs for the next month. In this study, we found that only $17.9 \%$ CHCs have a team who is responsible for drug removal. The team was important to verify that the drugs indeed had to be removed. Nevertheless, most of the CHCs understand and apply the principles of lost or damaged drug management. As much as $94.9 \%$ CHCs have a good management of their drug stock, to keep the optimum stock to avoid drugs stockpile, regularly do the stock checking and drugs expired date checking.

The prescription assessment was performed in $71.8 \%$ CHCs by the pharmacist or pharmacy technicians. Almost all the CHCs (94.7\%) prepared drugs in accordance with the prescriptions and deliver information on the regiments to the patients. The concern is that only $30.8 \%$ of the prescriptions were written by doctors or dentists, while the rest were written either by nurses or midwives, who were not listed in the health law. The counselling (23.1\%) and home visit $(7.7 \%)$ as part of clinical pharmacy services for supporting the PISPK program have low performances in this study.

\section{DISCUSSION}

West Java is the most populous province in Indonesia, thus having the most number of accredited CHCs. There are about 10,134 units of CHCs all over Indonesia, and most of them are located in West Java Province, which counted about 1,069 CHCs units [1]. As the support systems for the PIS-PK program, the CHCs need some details to be improved, especially in the pharmaceutical information management system, and the number and competencies of human resources.
Most of CHCs in the sampling area has been accredited to guarantee the quality of their services. Inpatient CHCs were most located in rural areas $(38.5 \%)$ while outpatients CHCs were most located in urban areas (33.3\%), as there are not many hospitals in rural areas thus, the CHCs became the primary services for inpatients.

The competencies of pharmacists and pharmacy technicians will affect the CHC's pharmacy services significantly [8]. However, from this study, it was found that only $33 \%$ of the CHCs were qualified with the minimum number of pharmacy technicians. This lack of human resources happened due to financial limitations. To provide good pharmaceutical and clinical pharmacy services, professional human resources must be available. Another strategy to enhance a good quality service is by increasing human resources' competency, such as by training [8]. However, the data showed only $20.5 \%$ of pharmacists get chances for attending the training. The amount of in-house training should be added as the solution for human resource problems. Webinar and e-learning can be utilised. Staffexchanges between health centres, and internship programmes were also recommended. The lack of training programmes will affect not only on the human resources competency but also the inadequate credits for the Pharmacist Registration Certificate renewal, which is needed for the pharmacist work permit [9].

The pharmaceuticals and consumables inventory management includes stock planning, stock demand, stock receiving, storage, stock distribution, stock rotation and expiry monitoring, stock removal, and stock reporting $[10,11]$. The result of the study showed that most of the CHCs have good inventory management, except for the storage system. A good drug storage system should have good lighting, air circulation, humidity, volume, etc [6]. Minimum fund support becomes the main reason for this unqualified facility.

When this study was conducted, the DURRS was recorded on a paperbased system. The paper-based system has several weaknesses such as time consuming; lack of accuracy, not real time, delay in making decisions on distribution; cannot detect the expiry date of medicine [11].

An efficient Pharmaceutical Management Information Systems (PMIS) will be able to continuously analyse large amounts of data from the pharmaceutical operation process, and help the management in managing the inventories, decision making, and activities documentation. In other words, the system will improve the whole units' performances [12]. In 2013, Tanzania introduced a national web-based electronic logistics management information system (eLMIS) to support the aggregating, reporting and visualising of data collected from the paper-based system. The system implemented in Tanzania succeeds in improving their data access and usage, visibility and transparency, better planning, management and monitoring, especially to forecast the supply need. The same system was also applied in Zambia and decreased the pharmaceutical vacancy rate from $15 \%$ to $0 \%$. Internet-based PMIS helps in reducing storage costs and maintenance, faster decisions in pharmaceuticals distribution, as well as multi-site data access, including the stocks' expired dates [11]. An online reporting system together with appropriate training is recommended to be applied to Indonesia CHCs, to improve and integrate the data report in real time. Perhaps this will give benefits for long-term efficiency and budget-saving, as well as solving the human resources problem. 
For decades, pharmacists have broadened their scope beyond traditional distributive and dispensing roles. Pharmacists' interventions and good interaction between pharmacists, physicians, and the patients themselves helped optimize the quality of medication and disease management, referred to as clinical pharmacy services [13]. Currently, the clinical pharmacy services have expanded both in terms of skills and areas of services. While traditionally, the services stay in hospitals to reduce the length of stay and mortality, now a home-visit service is recognised for outpatient settings, especially those with chronic diseases or need long-term monitoring $[14,15]$.

In the PIS-PK program, CHCs do the pharmacy home services, especially for patients with tuberculosis, hypertension and mental health diseases who received long-term treatments. The data showed that only a few CHCs performed home visits due to the burden of administrative tasks for the pharmacist. The three PIS-PKfocused diseases need regular counselling to ensure patient compliance to their treatments, monitor the side effects and prevent the spread for patients with tuberculosis [3]. This study also found that the availability of tuberculosis, hypertension and mental health diseases drugs is low, and not fulfilled by the public health office. Thus, the CHCs strive for it independently to guarantee continuity in their patients' treatment. The availability of medicine, especially tuberculosis medicine, is critical to avoid drug resistance. Having adequate medicines for a year will eliminate the risk of drug resistance for the patients with tuberculosis [19].

Many factors were needed to perform a good home visit program, such as human resources competencies, and the patients adhere to the activities during a home visit. Thus, training, education, and qualification improvements for pharmacists and pharmacy technicians must be sought. A good collaboration between pharmacists and other healthcare professionals supported with qualified technology will be expected $[14,15]$.

The limitation of this study is the minimal sampling area focusing only on West Java using self-reported observation data. The representation data should be improved and validated to generalize the findings into the West Java area in the future study.

\section{CONCLUSION}

As the main facility for the PIS-PK program, most CHCs in West Java Province have applied good pharmaceuticals and consumables inventory management, although this can be improved by developing an online PMIS, so real-time data can be obtained and the management system can be integrated. The minimum requirement for human resources in number and competencies must be fulfilled, by increasing the training opportunities, to improve the quality of clinical pharmacy standard services, especially in counselling services and home visit for three focused diseases. E-learning and internship programmes at CHCs can be considered, and government contribution in funding support is needed.

\section{FUNDING}

Nil

\section{AUTHORS CONTRIBUTIONS}

All the authors contributed equally.

\section{CONFLICT OF INTERESTS}

Declared none

\section{REFERENCES}

1. Kementerian Kesehatan RI. Keputusan menteri kesehatan republik Indonesia nomor tentang data pusat kesehatan masyarakat per akhir desember tahun 2019 [in Bahasa Indonesia]. Jakarta: Kementerian Kesehatan RI; 2019.

2. Kementerian Kesehatan RI. Peraturan menteri kesehatan republik Indonesia nomor 74 tahun 2016 tentang standar pelayanan Kefarmasian di puskesmas [in Bahasa Indonesia]. Jakarta: Kementerian Kesehatan RI; 2016.

3. Kementerian Kesehatan RI. Tentang pedoman penyelenggaraan PIS-PK program Indonesia sehat dengan pendekatan keluarga [in Bahasa Indonesia]; 2016. p. 2016.

4. Kementerian Kesehatan RI. Program Indonesia sehat dengan pendekatan keluarga [in Bahasa Indonesia]. Jakarta: Kementerian Kesehatan RI; 2017.

5. Kementerian Kesehatan RI. Peraturan menteri kesehatan republik Indonesia nomor 75 tahun 2014 tentang pusat kesehatan masyarakat [in Bahasa Indonesia]. Jakarta: Kementerian Kesehatan RI; 2014.

6. Embrey M-3. Managing access to medicines and health technologies. Arlington: Management Sciences for Health, Inc; 2012.

7. Kementerian Kesehatan RI. Pelatihan manajemen puskesmas dengan pendekatan keluarga [in Bahasa Indonesia]. Jakarta: Kementerian Kesehatan RI; 2017.

8. Penm J, Moles R, Wang H, Li Y, Chaar B. Factors affecting the implementation of clinical pharmacy services in China. Qual Health Res. 2014;24(3):345-56. doi: 10.1177/1049732314523680, PMID 24562375.

9. Kementerian Kesehatan RI. Peraturan pemerintah republik Indonesia nomor 51 tahun 2009 tentang pekerjaan Kefarmasian [in Bahasa Indonesia]. Jakarta: Kementerian Kesehatan RI; 2009.

10. Holloway KA. Indonesia pharmaceuticals in health care delivery. New Delhi: World Health Organization, regional Office for South East Asia; 2011.

11. Keerthi AM, Ramapriya S, Kashyap SB, Gupta PK, Rekha BS, Pharmaceutical management information systems: a sustainable computing paradigm in the pharmaceutical industry and public health management. In: Ahad MA, Paiva S, Zafar S. editors Sustainable and energy-efficient computing paradigms for society. Gewerbestrasse. Springer International Publishing; 2021. p. 33-51.

12. Thrower M, Felkey B. Managing technology and pharmacy information systems. In: Pharmacy management. 2nd ed. New York: McGraw-Hill Companies, Inc; 2009. p. 79-95.

13. Rotta I, Salgado TM, Silva ML, Correr CJ, Fernandez-Llimos F. Effectiveness of clinical pharmacy services: an overview of systematic reviews (2000-2010). Int J Clin Pharm. 2015;37(5):68797. doi: 10.1007/s11096-015-0137-9, PMID 26001356.

14. Mackeigan L, Nissen L. Clinical pharmacy services in the home. Dis Manag Health Out. 2008;16:227-44.

15. Flanagan PS, Barns A. Current perspectives on pharmacist home visits: do we keep reinventing the wheel? Integr Pharm Res Pract. 2018;7:141-59. doi: 10.2147/IPRP.S148266, PMID 30319952.

16. Karuniawati H, Putra ON, Wikantyasning ER. Impact of pharmacist counseling and leaflet on the adherence of pulmonary tuberculosis patients in lungs hospital in Indonesia. Indian J Tuberc. 2019;66(3):364-9. doi: 10.1016/j.ijtb.2019.02.015, PMID 31439181. 